\title{
The felsic dikes of La Gomera (Canary Islands): identification of cone sheet and radial dike swarms
}

\author{
E. Ancochea ${ }^{\mathrm{a}, *}$, J.L. Brändle ${ }^{\mathrm{a}}$, M.J. Huertas ${ }^{\mathrm{a}}$, C.R. Cubas ${ }^{\mathrm{b}}$, F. Hernán ${ }^{\mathrm{b}}$ \\ a Departamento Petrología y Geoquímica, Facultad de CC.Geológicas, Instituto Geología Económica, \\ CSIC - Universidad Complutense, 28040 Madrid, Spain \\ b Departamento Edafología y Geología, Universidad de La Laguna, 38204 La Laguna, Tenerife, Spain
}

Received 24 July 2001; accepted 29 May 2002

\begin{abstract}
On the northern part of La Gomera there exists a great abundance of trachytic-phonolitic dikes showing a broad diversity in dip and strike. Several methods have been applied in order to separate these dikes in different sets, localise the area from where they derive, and reconstruct the geometry of the swarms. The oldest dikes correspond to a radial swarm dated at $8 \mathrm{Ma}$. The felsic activity migrated then southwestwards and a second radial swarm and a cone sheet complex were developed between 7.5 and $6.4 \mathrm{Ma}$ ago. The cone sheet complex is $10 \mathrm{~km}$ in diameter and shared its centre with that of the second radial structure. The cone sheets exhibit an outward decrease of dip angle whilst every individual sheet maintains a constant inclination. This geometry reflects the existence of an ancient single domeshaped shallow magma chamber situated some $1650 \mathrm{~m}$ below present sea level. The eastern radial swarm represents a felsic episode that could mark the ending of the Lower Old Basalts, the earlier subaerial activity of La Gomera. The two other dike swarms represent a younger episode coeval with the Upper Old Basalts.
\end{abstract}

Keywords: felsic dikes; cone sheet swarms; radial dike swarms; La Gomera

\section{Introduction}

Although intrusive episodes play an important roll in the growth of oceanic islands, references on this topic are not abundant. This is even more evident when referred to felsic magmatism. Schirnick et al. (1999) have recently commented how

* Corresponding author.

E-mail address: geodec@eucmax.sim.ucm.es

(E. Ancochea). important intrusive episodes are in the understanding of volcanic islands and have shown the importance of detailed studies on dike swarms as a useful tool for inferring the location and shape of relatively shallow magma chambers. Long-lasting volcanic constructions, such as those built up by the early subaerial activity on the Canary Islands, are often related to complex dike patterns reflecting the great diversity of episodes involved in their history. On the other hand, the deep erosion levels reached on some of them provide an exceptional opportunity to study the structure of dike swarms. Nevertheless, the complexity of 
these dike patterns has made their identification difficult, and discrimination in general is only possible when a detailed study is carried out.

Felsic dike swarms are common and are typified on the Canary Islands by for example: the Tejeda cone sheet swarm on Gran Canaria (Schmincke, 1967; Hernán, 1975, 1976; Hernán and Vélez, 1980; Schirnick et al., 1999), the Vega del Río de Palmas ring complex on Fuerteventura (Muñoz, 1969; Stillman et al., 1975) and the Las Cañadas cone sheet swarm on Tenerife (De la Nuez et al., 1989; Ancochea et al., 1999). Rather less well known is the important felsic diking on La Gomera. Only Cendrero (1971) and Rodríguez Losada (1987, 1988) have cited the abundant felsic dikes near Vallehermoso on the northern part of La Gomera which are studied and described in the present paper. We present here new structural and geochronological data on these trachytic-phonolitic dikes. We also identify and reconstruct the geometry of the dike swarms and deduce the situation of their hypothetical feeding magma chambers.

The present authors (Brändle et al., 1991) developed a method for the identification of radial dike swarms and the localisation of their centres that has been applied successfully in the recon- struction of deeply eroded basaltic shields on Fuerteventura (Ancochea et al., 1993, 1996). In this method, each dike was considered to be a straight line which, in the case of radial swarms, would converge on the radial swarm centre. The area where the intersections of lines reach its maximum would represent this hypothetical centre. This method is applied in several steps: the first step is the estimation of the hypothetical centre interpreted as the area where the number of intersections is maximum. Then, all dikes that could be assembled around this hypothetical centre are separated. A dike is considered to belong to the deduced centre only when the angle between the measured dike strike and the hypothetical radius (the line jointing the point of measurement to the centre) is smaller than a predetermined value $\left(5^{\circ}\right.$ or $10^{\circ}$ ) and else when the distance from the dike strike prolongation to the centre is less than a given value (in this case $1 \mathrm{~km}$ ). Once all dikes matching these necessary conditions are separated, the first step is reinitiated using only them, in order to obtain a more precise position of the centre. The process is repeated several times until the variations in the position of the centre and the number of dikes matching do not change significantly.

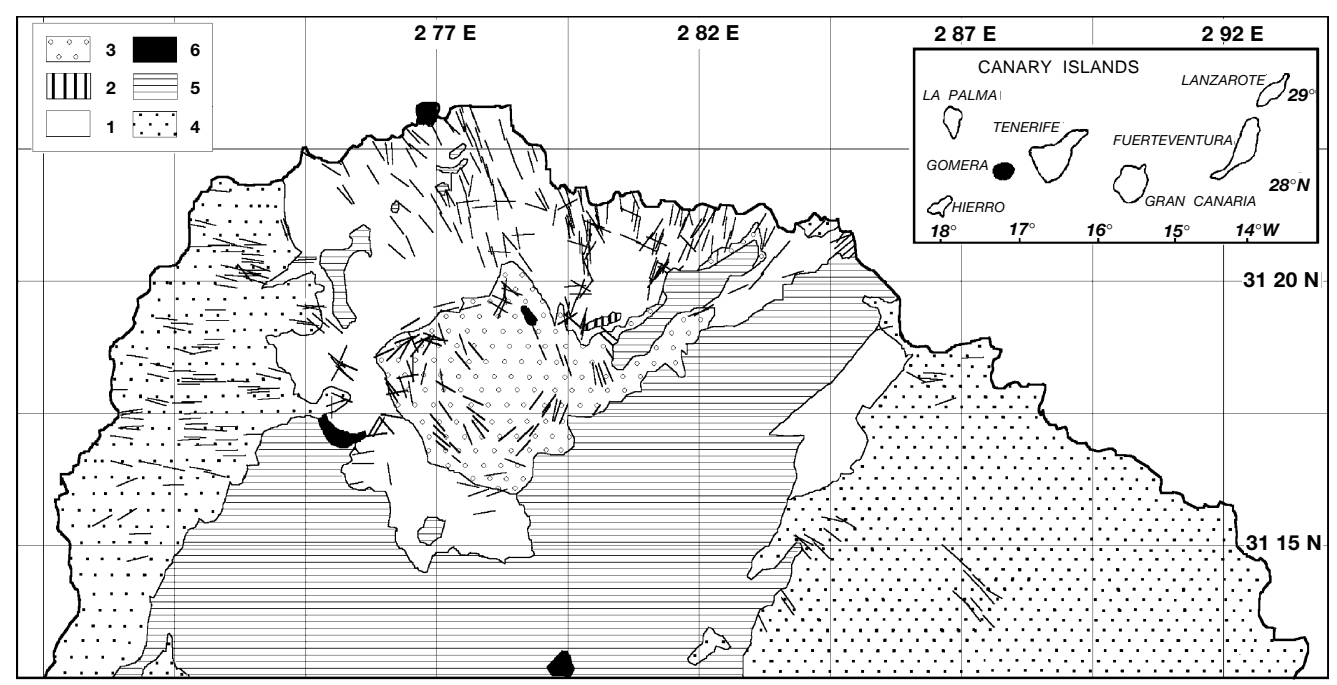

Fig. 1. Geological sketch of the northern area of La Gomera and distribution of felsic dikes. 1: Basal Complex; 2: Tamargada syenite; 3: T-PhC; 4: Old Basalts; 5: Recent Basalts; 6: Recent Felsic Domes. In all figures: labeled coordinates refer to 5 km division of the UTM grid system (sector 28). 


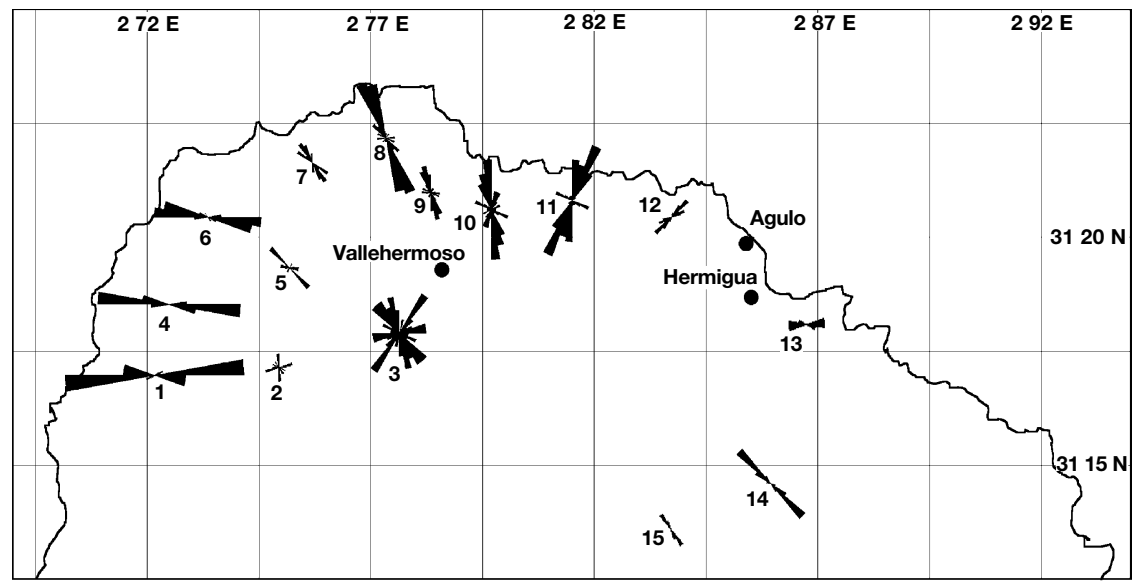

Fig. 2. Rose diagrams of felsic dikes on the different sectors. The rose diagram size is proportional to the number of dikes (all figures).

\section{Geological setting}

La Gomera, one of the western Canary Islands, has an almost circular area of $380 \mathrm{~km}^{2}$ and a maximum height of $1487 \mathrm{~m}$ (Fig. 1). The oldest unit, the Basal Complex, is formed of basic plutonic rocks and an isolated syenitic outcrop (Tamargada syenite), submarine sediments and volcanic materials, cut by a dense mainly basic dike network. Abdel Monen et al. (1971) obtained two ages from the Basal Complex (19.3 and 14.6 Ma) and Cantagrel et al. (1984) one from a gabbro $(15.5 \mathrm{Ma})$ and another one from the syenite $(9.1 \mathrm{Ma})$, all interpreted by these authors as minimum ages due to the existence of later thermal processes affecting the rock.

Resting unconformably over the Basalt Complex are the Old Basalts in which three subunits are distinguished: the Lower Old Basalts, the Polymict Volcanic Breccias and the Upper Old Basalts (Bravo, 1964; Cendrero, 1970, 1971). According to Cantagrel et al. (1984) and Cubas et al. (1994) the age of this unit is between 11 and $6 \mathrm{Ma}$.

Another older unit is the trachytic-phonolitic complex (T-PhC) (Cendrero, 1971; Rodríguez Losada, 1988) which is composed of trachyticphonolitic lava flows, pyroclasts, breccias, dikes and domes. This unit lies unconformably over the Basal Complex. The stratigraphic relation- ship of the T-PhC with the Old Basalts is not clear since the units are never in direct contact (Fig. 1).

The later units are a group of salic domes and flows (4.6-3.9 Ma after Cantagrel et al., 1984) and, finally, the Recent Basalts that spread southwards (5.3-2.8 Ma after Feraud (1981), Feraud et al. (1985) and Cantagrel et al. (1984)). No quaternary activity has been reported on La Gomera.

\section{Felsic dikes}

Felsic dikes are ubiquitous in the northern area of La Gomera where they intrude into the older formations: the Basal Complex, the Old Basalts and the T-PhC (Bravo, 1964; Cendrero, 1970, 1971; Hausen, 1971; Cubas, 1978; Rodríguez Losada, 1988). Felsic dikes are not found in the younger basalts that overlay all the older materials (Fig. 1).

Cendrero (1971) supposed that the felsic dikes formed a radial pattern around the $\mathrm{T}-\mathrm{PhC}$ and suggested a genetic relationship between these salic dikes and the T-PhC. By contrast Rodríguez Losada $(1987,1988)$ advanced the idea of a conical pattern centred at the core of the T-PhC and, though he admitted that some of the dikes were not conical, this author denied the existence of a true radial pattern. 


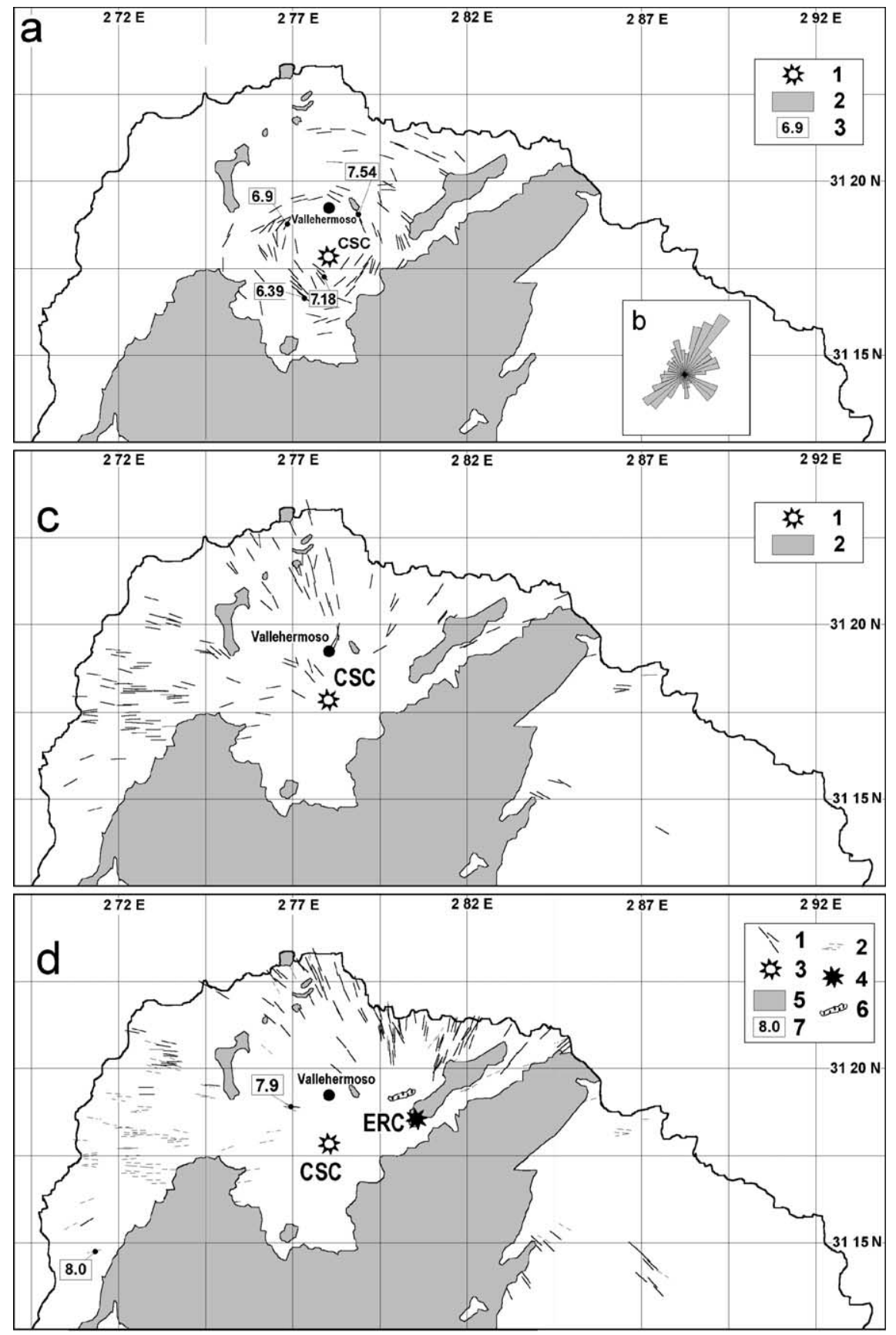

Fig. 3. Felsic dike swarms: (a) distribution of cone sheet dikes: 1: estimated CSC; 2: recent units; 3: age (Ma). (b) Dip-strike rose diagram of VCSS. (c) Dikes belonging to the WRS, associated with the cone sheet centre: 1: estimated CSC; 2: recent units. (d) Dikes belonging to the ERS: 1: dikes exclusively from the ERS; 2: dikes coherent with both radial dike-swarm focuses; 3: estimated CSC; 4: estimated ERC; 5: recent units; 6: Tamargada syenite; 7: age (Ma). 

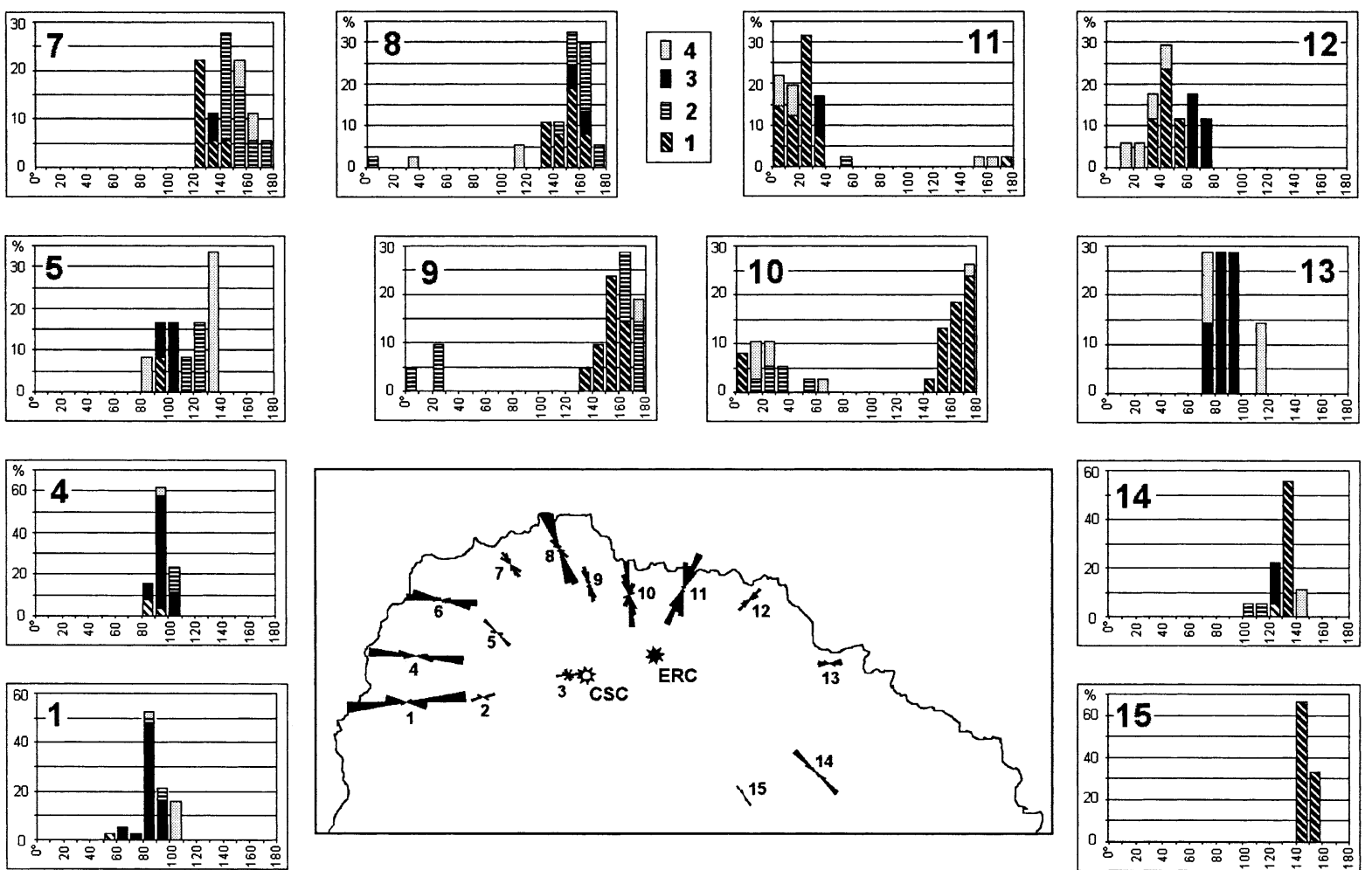

Fig. 4. Rose diagram projected on La Gomera map. Representative histograms of the radial dikes. Histograms (frequency \%): 1: dikes belonging to the ERS; 2: dikes belonging to the WRS; 3: dikes coherent with both radial dike-swarm focuses; 4: dikes not coherent with any of the centres.

\subsection{Identification of the dike swarms}

Some 450 direction, dip angle, and thickness measurements were recorded throughout the entire area of dikes exposure, covering a total height of more than $600 \mathrm{~m}$.

At first sight two different groups of dikes were easily distinguished: most $(80 \%$ of the total amount of dikes) were vertical to near-vertical and converged inland forming an apparent radial pattern (Figs. 1 and 2). The rest of them (20\% of the dikes) were clearly inclined. The plunge directions of this latter dike assembly allowed us to identify this group as a possible cone sheet swarm. On the other hand, the detailed analysis of the vertical and subvertical radial dike strikes has revealed the existence of a double radial pattern.

All the dikes, felsic in composition, plot on the TAS diagram (IUGS) near the trachytes-phono- lites field boundary. Besides, no significant relationship between dike composition and dike structure or between dike composition and age has been appreciated.

\subsection{The cone sheet swarm}

The inclined dikes constitute in fact (Fig. 3a,b) a cone sheet swarm intruding into the Basal Complex and into the T-PhC. No conical dikes are found, however, intruding into the Old Basalts, which is probably due to the fact that the Old Basalts are exposed too far from the cone sheet swarm centre (CSC; Fig. 1). Although many of them are individual conical dikes, some others crop out as packs of thick conical dikes forming structures denominated by Rodríguez Losada (1987) as 'dome-dikes', due to their prominent erosive shape resembling that of domes. 
In order to locate the coordinates of the centre, in the case of a cone sheet swarm we must use dike plunge directions instead of dike strikes. According to this, the CSC (estimated from all the conical dikes measured in the field) lies on a sector situated around the point $3.117 .800 \mathrm{~N}$ and $2.78 .000 \mathrm{E}$ (UTM coordinates), $1.5 \mathrm{~km}$ south of Vallehermoso village (Fig. 3a), near the area suggested previously by Rodríguez Losada (1987, 1988).

As we indicate later, cone sheets show different dip and thickness and are also differently spaced. These features would seem typical of a multiple structure, the result of several episodes that were superimposed in space and time, and similar to some of the models described by Schirnick et al. (1999). We have estimated the location of the hypothetical centre by considering separately: 1 : individual cone sheets, 2: packs of thick conical dikes, 3: cone sheet dikes from the core of the conical structure, 4: cone sheet dikes from the periphery, 5: steeply dipping cone sheet dikes and 6: gently dipping cone sheet dikes. The position deduced for the centre remains invariable regardless of the group of dikes used in the determination. This fact is more in agreement with a single structure and a fixed emplacement of the feeding magma chamber.

\subsection{Radial dike swarms}

The strikes of the vertical dikes follow a general radial pattern. Nevertheless, whilst their distribution is clearly uniform in some sectors (i.e. stations 1, 4, 14, or 15 in Fig. 4), it is more poorly defined or even follows a double pattern in some others (i.e. stations 5, 7, 10 and 12). The existence of these sectors showing two different dike strikes (normally separated by $20-30^{\circ}$ ) points to the presence of two different families of radial dikes.

Given the very frequent association of radial dikes and cone sheets, we can suppose that one of the two radial dike families could proceed from a magmatic focus located close to that deduced for the cone sheet swarm. In our example, this is supported by the common association of cone sheets and perpendicular radial dikes in the field, and also by some of the rose diagrams (i.e. sectors 10 and 11 in Fig. 2).

If CSC is supposed to be the convergent centre of one of the radial swarms, we can discriminate, by using an inverse method, how many of the radial dikes really converge in that centre. Of the total amount of radial dikes, up to $43 \%$ converge in CSC, and so define a radial swarm that we have called as the western radial swarm (WRS).

The remaining dikes define another radial pattern (Fig. 3d). The area where their imaginary prolongations show a higher number of intersections provides a centre located roughly at the point 3.118.500 N and 2.80.500 E (UTM coordinates), east of the CSC. Most (78\%) of these remaining radial dikes are coherent with this centre (the eastern radial centre) around which what we have called the eastern radial swarm (ERS) extends.

This centre is close to the area where the only existent syenites on La Gomera, the Tamargada syenites, are exposed. This fact could represent a sign of possible genetic relationship between this radial structure and the syenitic rocks.

Table 1

$\mathrm{K}-\mathrm{Ar}$ radiometric ages

\begin{tabular}{lllllll}
\hline Sample & Dike type & UTM coordinates & $\begin{array}{l}{ }^{40} \mathrm{Ar} * \\
\left(\mathrm{scc} / \mathrm{g} \times 10^{-5}\right)\end{array}$ & $\begin{array}{l}{ }^{40} \mathrm{Ar} * \\
(\%)\end{array}$ & $\begin{array}{l}\mathrm{K} \\
(\%)\end{array}$ & $\begin{array}{l}\text { Age }( \pm 1 \sigma) \\
(\mathrm{Ma})\end{array}$ \\
\hline $47910^{\mathrm{a}}$ & Buenavista cone sheet dike pack & $3.118 .500-2.79 .440$ & 0.114 & 20.8 & 3.89 & $7.54 \pm 0.55$ \\
G-78 $^{\mathrm{a}}$ & Garabato cone sheet dike pack & $3.117 .190-2.77 .790$ & 0.125 & 29.8 & 4.47 & $7.18 \pm 0.39$ \\
$47862^{\mathrm{a}}$ & La Parra cone sheet dike pack & $3.116 .310-2.77 .440$ & 0.114 & 19.8 & 4.57 & $6.39 \pm 0.47$ \\
G-84 $^{\mathrm{b}}$ & Cone sheet dike & $3.118 .980-2.76 .500$ & 0.118 & 35.4 & 4.40 & $6.90 \pm 0.40$ \\
G-85 $^{\mathrm{b}}$ & Radial dike & $3.118 .980-2.76 .500$ & 0.126 & 71.2 & 4.13 & $7.90 \pm 0.40$ \\
G-1 $^{\mathrm{b}}$ & Radial dike & $3.114 .470-2.71 .200$ & 0.113 & 92.5 & 3.73 & $8.00 \pm 0.30$ \\
\hline
\end{tabular}

a Determinations made in Hungarian Science Academy.

b Determinations made by Teledyne Isotopes Lab (USA). 


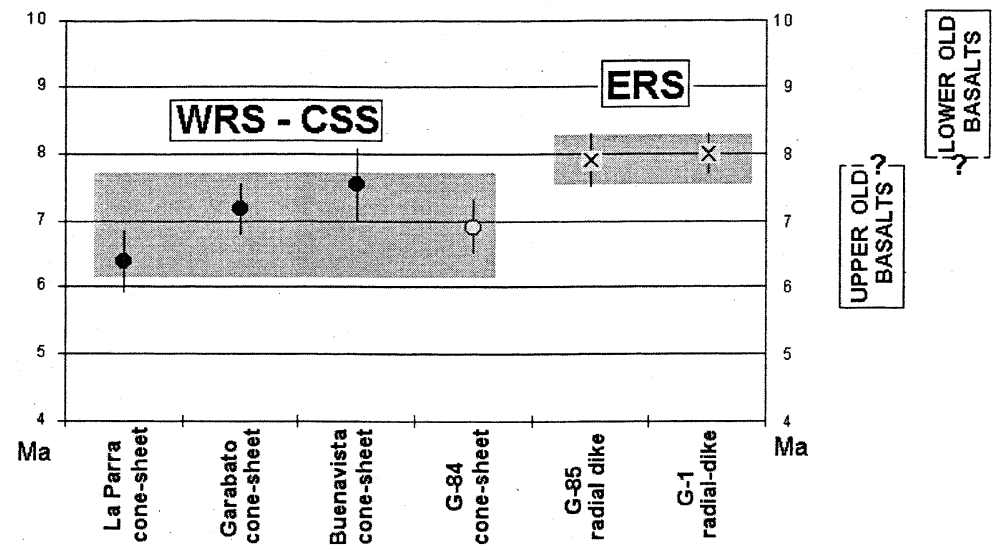

Fig. 5. K/Ar radiometric ages from the felsic dikes and their chronological relationship with the Lower Old Basalts and the Upper Old Basalts.

In sum, all radial dikes are essentially distributed in two different families, the WRS associated to the cone sheet swarm and an independent ERS. About $43 \%$ of the total amount of radial dikes might belong to the WRS and $66 \%$ to the ERS. Considering only these dikes, about $21 \%$ of them (those roughly W-E) could belong to either of the swarms, because the double structure cannot be evidenced in those sectors where all radial dikes are aligned with both the CSC and ERC centres (i.e. sectors 1, 2 and 13), and so follow a very similar trend that constrains their discrimination.

\subsection{Age}

The extensive hydrothermal alteration of most dikes reduces considerably the geochronological study of the La Gomera felsic dike swarms. Nevertheless, six K/Ar radiometric determinations have been carried out from some laboriously selected unaltered or only slightly altered samples (Table 1 and Fig. 5).

Some thick cone sheet dikes from the packs yield ages of 7.54, 7.18 and $6.39 \mathrm{Ma}$, and an individual cone sheet dike (G-84) a very similar one, of $6.9 \mathrm{Ma}$.

Only two samples from radial dikes were suitable for geochronological analysis. One of them (G-85) belonging to the ERS yields an age of 7.9 Ma. Although on the basis of its field location the other sample (G-1) could be ascribed to any of the centres (Fig. 3d), its resulting age $(8.0 \mathrm{Ma})$ is very similar, and thus, it most likely belongs to the same swarm (ERS). No age from the other radial swarm (WRS) has been determined. Notwithstanding that they are associated with the conical swarm, the WRS dikes must be similar in age to the conical sheets, and so younger than the ERS.

\section{Geometry of the cone sheet swarm}

Although the cone sheet dikes are more abundant in the northeastern and southwestern sectors, and less frequent in the northwestern area of the structure, they outline a complete annular

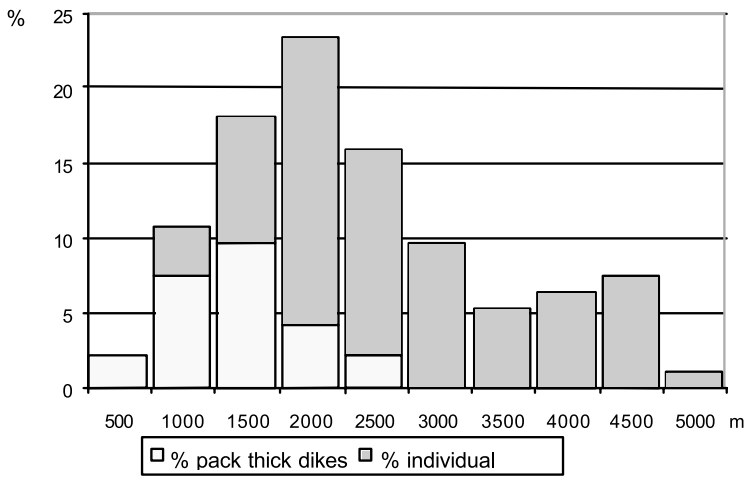

Fig. 6. Distribution of cone sheet dikes versus distance to centre. 


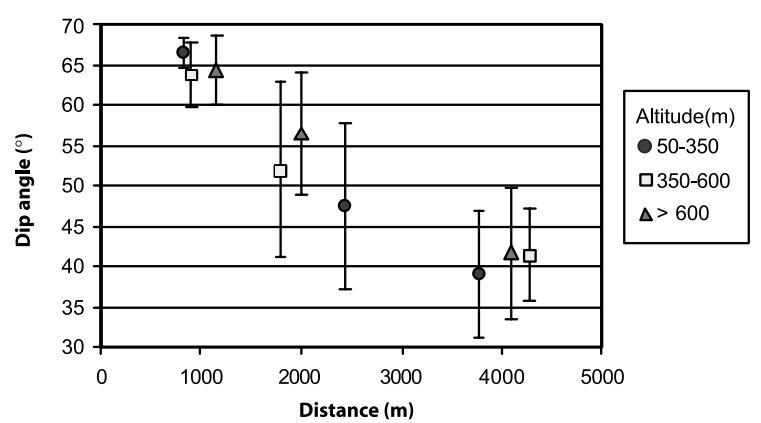

Fig. 7. Variation of cone sheet dip angles with distance at different altitudes. The mean value with standard deviation error bars is indicated for each one of the groups considered in the text. The distance represented in the figure is a mean distance for each group of dikes.

pattern (Fig. 3a,b). This contradicts the assertion of Rodríguez Losada (1987, 1988) who alleged that the structure was open to the NW. In our opinion the existence of younger deposits can account for the lesser amount of conical dikes in this area.

The cone sheet dikes are concentric around the CSC and describe a ring some $10 \mathrm{~km}$ in diameter at sea level. The packs concentrate between 400 and $2000 \mathrm{~m}$ from the CSC (Fig. 6). These structures are composed of dense packs of thick cone sheet dikes (20-30 or more metres) within which host rock screens are absent or scarce, the average dike density being about $20 \%$. Individual 2-3-mthick cone sheets occur from 700 to $5000 \mathrm{~m}$ away from the centre (Fig. 6). They are especially evident in the outer part of the structure where they represent a dike density of about $1-2 \%$.

Dip angles range from $70^{\circ}$ to $30^{\circ}$. We have studied the variation of cone sheet dip angles distinguishing three arbitrary annular zones by dis- tance from the CSC $(<1500 \mathrm{~m}, 1500-3000 \mathrm{~m}$ and $>3000 \mathrm{~m})$ and three also arbitrary zones of different elevation (50-350 m, 350-600 m and $>600 \mathrm{~m}$ ) (Fig. 7). Cone sheet dips measured along radial transects decrease gradually from core to rim of the structure. Cone sheet dikes in the inner part of the structure, less than $1500 \mathrm{~m}$ from the CSC, show dip angles $\geq 55^{\circ}$; the less inclined dikes $\left(30-45^{\circ}\right)$ appear more than 3000 $\mathrm{m}$ distant from the centre. Conical dikes belonging to the packs of thick dikes dip between $45^{\circ}$ and $70^{\circ}$ (the mean dip angle being $64^{\circ}$ ), whilst individual cone sheet dikes dip $30-70^{\circ}$ (the mean being $47^{\circ}$ ).

The lack of any variation in cone sheet dip angles with elevation (Fig. 7) allows us to suppose that the inclination remains constant down to the swarm root, near the focus.

In view of all this, the Vallehermoso cone sheet swarm (VCSS) corresponds to a single structure characterised by an outward decrease of dip angle, every individual dike maintaining a constant dip. Our model is thus similar to the classical one described by Anderson (1936) and differs from curved inclined cone sheet swarm models like those of Phillips (1974) and Gudmundsson (1998). The model is also different from those maintaining an average dip angle from centre to rim such as the Tejeda cone sheet swarm on Gran Canaria described by Schirnick et al. (1999).

One more aspect is the estimation of a depth for the focus. Hernán and Vélez (1980) calculated a shallow depth (roughly $2000 \mathrm{~m}$ below sea level) for the Tejeda cone sheet swarm focus by taking the depth of the hypothetical plane on which intersections of dip directions showed a higher concentration. We have used a similar method to

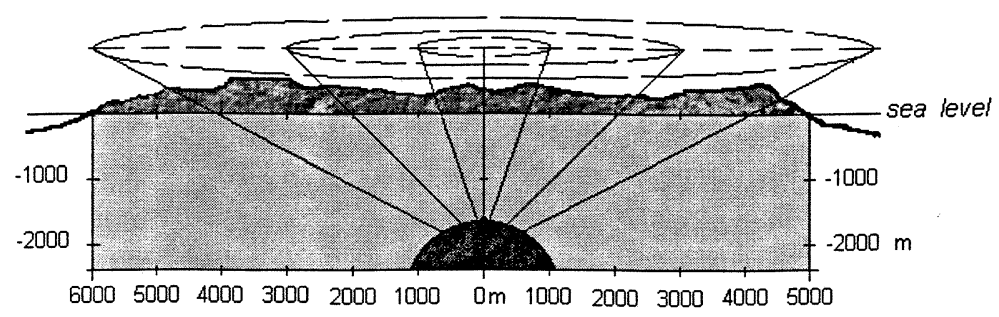

Fig. 8. Geometrical scheme of the Vallehermoso cone sheet complex. 
localise the depth of the VCSS focus, estimated as the plane that minimises the distance of the dip direction lines to the vertical located at the centre.

If the overall amount of cone sheets is taken into account, the estimated depth for the focus is $2100 \mathrm{~m}$ below present sea level. This depth is a mean value, however; as shown in Fig. 8, the depth under the central core of the structure might be shallower. The latter could be roughly that of the plane where the convergence of the innermost cone sheet dikes is a maximum, about $1650 \mathrm{~m}$ below sea level.

In sum, the VCSS developed a single complete structure and shared its centre (CSC) with the second radial structure. No variation of dip with elevation is observed; however an outward decrease is apparent in the conical structure. These facts reveal the presence of a shallow ancient dome-shaped magmatic body.

\section{Discussion and conclusions}

As stated above, three different dike swarms, intruding possibly in two separated time episodes, are identified on the north of La Gomera. The oldest radial swarm, the eastern one (ERS), intruded at about $8 \mathrm{Ma}$, is centred in the vicinity of Tamargada and might be related to the syenites exposed in this area. About $7.5 \mathrm{Ma}$ ago the activity migrated some $2.5 \mathrm{~km} \mathrm{SW}$ giving rise to a second radial swarm (WRS) and a cone sheet swarm (VCSS).

Since such intrusive episodes may have played an important roll in the volcanological evolution of the island, it can be of great interest to correlate them with the main effusive episodes that built up La Gomera.

Although both of the felsic intrusive episodes are roughly coeval with the Old Basalts (11-6 $\mathrm{Ma})$, the chronostratigraphy of this series is not known in sufficient detail as to make an accurate correlation. Thus, neither the stratigraphical nor the chronological limit between the Lower Old Basalts and the Upper Old Basalts is clearly defined. Cantagrel et al. (1984) place the limit at $9 \mathrm{Ma}$ on the basis of an age obtained for a sam- ple collected at the bottom of a 'barranco' in the south, that they interpret as early Upper Old Basalts. However the intense density of basic dikes and the high degree of weathering of the rocks in that area imply that the sample corresponds to the Lower Old Basalts. The limit between Lower and Upper Old Basalts must therefore be appreciably younger. The rocks undoubtedly interpreted as corresponding to the Upper Old Basalts yield ages of $7.5 \mathrm{Ma}$ or younger (Cantagrel et al., 1984).

The earlier felsic episode (ERS) would then be coeval with the late Lower Old Basalts, or else it might represent the ending of that magmatic cycle (Fig. 5). The later felsic episode (VCSS and WRS) has an age coinciding with the Upper Old Basalts.

The felsic plugs from Serie de Los Roques (4.6$3.9 \mathrm{Ma}$ ) scattered all over the island (a few within the area studied here, Fig. 1) represent a third independent felsic episode in the evolution of the island coinciding in time with the Recent Basalts.

If the age of $9.1 \mathrm{Ma}$ obtained by Cantagrel et al. (1984) from the Tamargada syenite is accepted, it is possible to correlate it with the ERS, and therefore with the first felsic episode. But if, on the contrary, the age is only a minimum age, as the authors themselves think, the syenite would represent a felsic episode prior to the dike swarms studied here.

The first episode, the ERS, is small and clearly less important in volume than the second one. Effusive or explosive activity related to it is not known. The younger second episode comprising the VCSS and the WRS has a larger volume. In the particular case of the cone sheet swarm, from the observed dike density and the estimated depth of its focus, a bulk volume of at least $5-10 \mathrm{~km}^{3}$ must be considered.

In the eastern and southern parts of the island a few felsic pyroclastic levels are interlayered with the Upper Old Basalts. According to their stratigraphical position, they could be ascribed to the second felsic episode. Finally, the presence of a cone sheet swarm and a shallow magma chamber allow us to speculate that this second episode could be accompanied by some caldera formation process. 


\section{Acknowledgements}

This work was supported by the Project PB980759. The authors thank L. Wilson and an anonymous referee for their constructive remarks.

\section{References}

Abdel Monen, A., Watkins, N.D., Gast, P.W., 1971. Potassium-argon ages, volcanic stratigraphy, and geomagnetic polarity history of the Canary Islands: Lanzarote, Fuerteventura, Gran Canaria and La Gomera. Am. J. Sci. 271, 490521.

Ancochea, E., Brändle, J.L., Cubas, C.R., Hernán, F., Huertas, M.J., 1993. La Serie I de Fuerteventura. Mem. R. Acad. C. Exac., Fís. y Natur. Madrid, 27, 151 pp.

Ancochea, E., Brändle, J.L., Cubas, C.R., Hernán, F., Huertas, M.J., 1996. Volcanic complexes in the eastern ridge of the Canary Islands: the Miocene activity of the island of Fuerteventura. J. Volcanol. Geotherm. Res. 70, 183-204.

Ancochea, E., Huertas, M.J., Cantagrel, J.M., Coello, J., Fúster, J.M., Arnaud, N., Ibarrola, E., 1999. Evolution of the Cañadas edifice and its implications for the origin of the Cañadas Caldera (Tenerife, Canary Islands). J. Volcanol. Geotherm. Res. 88, 177-199.

Anderson, E.M., 1936. The dynamics of formation of conesheets, ring dykes, and caldron-subsidences. Proc. R. Soc. Edinburgh 56, 128-157.

Brändle, J.L., Ancochea, E., Cubas, C.R., Hernán, F., 1991. Análisis de enjambres de diques radiales utilizando un método matemático. Geogaceta 10, 97-100.

Bravo, T., 1964. Estudio geológico y petrográfico de la isla de La Gomera. Est. Geol. 20, 1-56.

Cantagrel, J.M., Cendrero, A., Fúster, J.M., Ibarrola, E., Jamond, C., 1984. K-Ar chronology of the volcanic eruption in the Canarian Archipelago: Island of La Gomera. Bull. Volcanol. 47, 597-609.

Cendrero, A., 1970. The Volcano-plutonic complex of La Gomera (Canary Islands). Bull. Volcanol. 34, 537-561.

Cendrero, A., 1971. Estudio geológico y petrológico del Complejo Basal de la Isla de La Gomera (Islas Canarias). Est. Geol. 27, 3-73.

Cubas, C.R., 1978. Estudio de los domos sálicos de la isla de La Gomera (Islas Canarias). I. Vulcanología. Est. Geol. 34, 53-70.

Cubas, C.R., Hernán, F., Ancochea, E., Brändle, J.L., Huer- tas, M.J., 1994. Serie Basáltica Antigua Inferior en el sector de Hermigua. Isla de la Gomera. Geogaceta 16, 15-18.

De la Nuez, J., Cubas, C.R., Hernán, F., 1989. Los domos sálicos del Parque Nacional del Teide. In: Araña, V., Coello, J. (Eds.), Los volcanes y la caldera del Parque Nacional del Teide (Tenerife, Islas Canarias). Icona. pp. 177-185.

Feraud, G., 1981. Datation de réseaux de dykes et de roches volcaniques sousmarines par les méthodes $\mathrm{K}-\mathrm{Ar}$ et $40 \mathrm{Ar}-$ 39Ar. Utilisation des dykes comme marqueurs de paléocontraites. Thesis, Université de Nice, 146 pp.

Feraud, G., Giannerini, G., Campredon, R., Stillman, C.J., 1985. Geochronology of some Canarian dike swarms: contribution to the volcano-tectonic evolution of the archipelago. J. Volcanol. Geotherm. Res. 25, 29-52.

Gudmundsson, A., 1998. Magma chambers modeled as cavities explain the formation of rift zone central volcanoes and their eruption and intrusion statistics. J. Geophys. Res. 103, $7401-7412$.

Hausen, H., 1971. Outlines of the geology of Gomera. Soc. Sci. Fen. Com. Phys. Math. 41, 1-53.

Hernán, F., 1975. Estudio petrológico y estructural del complejo traquítico-sienítico de Gran Canaria. Thesis Doctoral, Universidad Complutense, Madrid.

Hernán, F., 1976. Estudio petrológico y estructural del complejo traquítico-sienítico de Gran Canaria. Est. Geol. 32, 279-324.

Hernán, F., Vélez, R., 1980. El sistema de diques cónicos de Gran Canaria y la estimación estadística de sus características. Est. Geol. 36, 65-73.

Muñoz, M., 1969. Estudio petrológico de las formaciones alcalinas de Fuerteventura, Islas Canarias. Est. Geol. 25, 257 310.

Phillips, W.J., 1974. The dynamic emplacement of cone sheets. Tectonophysics 24, 69-84.

Rodríguez Losada, J.A., 1987. Un complejo de diques cónicos en la isla de La Gomera, Islas Canarias. Est. Geol. 43, 4145.

Rodríguez Losada, J.A., 1988. El Complejo Traquítico-Fonolítico de La Gomera. Thesis Doctoral, Universidad Complutense, Madrid, $414 \mathrm{pp}$.

Schirnick, C., Bogaard, P.D., Schmincke, H.U., 1999. Cone sheet formation and intrusive growth of an oceanic island. The Miocene Tejeda complex on Gran Canaria (Canary Islands). Geology 27, 207-210.

Schmincke, H.U., 1967. Cone sheet swarm, resurgence of Tejeda Caldera, and the early geologic history of Gran Canaria. Bull. Volcanol. 31, 153-162.

Stillman, C.J., Fúster, J.M., Bennell-Baker, M.J., Muñoz, M., Smewing, J.D., Sagredo, J., 1975. Basal complex of Fuerteventura (Canary Islands) is an oceanic intrusive complex with rift-system affinities. Nature 257, 469-471. 